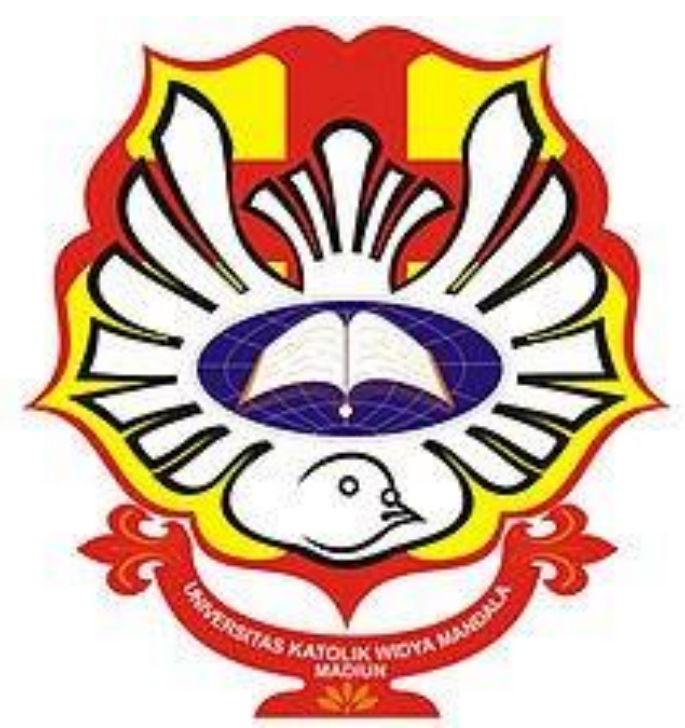

Tentang :

“CUCU TEGA TENDANG DAN PUKUL KAKEKNYA SENDIRI, PELAKU EMOSI GARA - GARA PAKAN IKAN “

Disusun Oleh :

Joy Prasasti Madiah Rahmadani / 41418004

UNIVERSITAS KATOLIK WIDYA MANDALA SURABAYA

KAMPUS MADIUN

FAKULTAS TEKNIK

TEKNIK INDUSTRI

2019 


\title{
CUCU TEGA TENDANG DAN PUKUL KAKEKNYA SENDIRI, PELAKU EMOSI GARA - GARA PAKAN IKAN
}

\begin{abstract}
ABSTRAK
Kekerasan fisik merupakan kekerasan yang dilakukan dengan melibatkan kontak langsung dan dimaksudkan untuk menimbulkan cedera atau penderitaan fisik yang lain. Kekerasan seringkali terjadi ketika seseorang tidak bisa mengendalikan emosinya. Inilah yang dialami oleh seorang kakek di daerah Kendal, beliau mengalami tindak kekerasan yang dilakukan oleh cucunya sendiri. Hanya karena hal sepele seorang pemuda ini tega memukuli dan menendang kakeknya sendiri. Berita ini sudah menjadi trending di media sosial dan seorang pemuda itu mendapat banyak kecaman dari warga net. Perlakuan pemuda ini dianggap sangat kelewat batas. Pemuda ini mengaku tidak dapat mengontrol emosi sehingga melakukan tindakan tersebut sehingga sampai hati melakukan kekerasan kepada kakeknya sendiri yang sudah tua. Raga sang kakek juga sudah tidak mampu untuk melawan cucunya, sehingga beliau hanya bisa pasrah. Perbuatan pemuda ini juga menyalahi nilai norma dan termasuk perbuatan yang sangat tidak baik.
\end{abstract}

\section{KEYWORDS}

Kekerasan fisik ; emosi ; pemuda 


\section{BAB I PENDAHULUAN}

\subsection{LATAR BELAKANG}

Pada zaman sekarang sangat banyak kasus kekerasan yang terjadi. Tidak hanya di negara ini saja tapi di seluruh dunia pun banyak sekali terjadi hal tersebut. Kekerasan yang terjadi saat ini terjadi di berbagai kalangan , mulai dari anak , remaja dewasa maupun lansia. Kekerasan oleh pelaku tidak hanya dilakukan terhadap orang lain saja, seringkali melibatkan orang- orang terdekat seperti adik, kakak, saudara, anak bahkan orang tua. Kebanyakan orang yang melakukan kekerasan dikarenakan tidak bisa mengontrol emosinya sehingga melakukan kontak fisik untuk meluapkan segala emosinya. Seseorang yang tidak bisa mengontrol emosinya akan sering marah bahkan hanya karena hal yang sepele. Seseorang yang emosional akan melakukan apapun untuk meluapkan emosinya bahkan sampai kehilangan kesadaran dan akal sehatnya. Seringkali orang yang emosional yang telah meluapkan emosional ke hal negatif akan merasa menyesal setelah kesadaranya pulih. Banyak sekali orang yang melakukan kesalahan dalam mengambil keputusan ketika emosinya tidak terkendali.

Hal ini terjadi pada seorang pemuda di Kendal yang melakukan kekerasan kepada kakeknya sendiri. Pemuda ini melakukan tindak kekerasan dengan memukili dan menendangi kakeknya sendiri. Diduga hal ini terjadi karena hanya masalah sepele yaitu pelet ikan yang ditaruh kakeknya di bak mandi. Pemuda ini sangat marah karena saat mandi terdapat pelet ikan di bak mandi dan sempat masuk ke mulutnya saat berkumur. Kejadian itulah awal mula pemuda ini marah sampai tidak bisa mengendalikan emosinya sehingga melakukan tindak kekerasan terhadap kakeknya sendiri. Berita ini viral di media sosial dan menjadi topik pembahasan warga net. Pemuda ini mendapat banyak kecaman dari warga net. Tindak kekerasan yang dilakukan pemuda ini adalah termasuk tindak kriminal dan sudah ditangani oleh pihak berwajib.

\subsection{TUJUAN}

Tujuan penulis membuat paper ini adalah sebagai kegiatan memberikan tanggapan dan melakukan pembahasan terhadap kasus kekerasan seorang cucu yang dilakukan kepada kakeknya sendiri. Dengan adanya paper ini di harapkan 
agar dapat menjadi suatu pelajaran dan pengetahuan untuk para pemuda agar melakukan sesuatu hal dengan selalu menyertakan akal budi.

\subsection{RUANG LINGKUP}

Berita ini diperoleh dari media sosial dimana sudah banyak warga net yang mengunggah kasus ini. Kemudian penulis melakukan pembahasan dengan berbagai teori yang terdapat di buku berjudul "Filsafat Manusia" oleh Dr. Agustinus W. Dewantara, S.S., M.HUM. Di dalam pembahasan paper ini membahas tentang kekerasan cucu terhadap kakeknya, langkah selanjutnya adalah melakukan identifikasi dan di terapkan dalam mata kuliah Filsafat Manusia.

\section{BAB II DASAR TEORI}

Kekerasan merupakan tindakan kriminal dan melanggar hukum dan norma. Baru- baru ini terjadi kasus kekerasan yang terjadi di Kendal yaitu seorang pemuda yang diketahui bernama Yusminardi(22) sebagai tersangka penganiayaan terhadap kakeknya sendiri Wasidi(65).

Peristiwa ini terjadi di Desa Kedungboto, Limbangan, Kendal, Jawa Tengah, pada Minggu 19 November 2019. Kejadian ini berawal dari tersangka sedang berada di kamar mandi, ketika ia menggosok gigi ia merasakan ada sesuatu yang masuk ke mulutnya. Ketika melihat kea rah bak mandi ia mnemui pelet ikan mengapung disana. Seketika itu Yusminardi sangat marah. Ia tidak dapat mengendalikan emosinya sampai-sampai menganiaya kakeknya sendiri dengan menendang dan memukuli kakeknya. Kejadian ini sempat di rekam oleh sepupu Yusminardi yang juga cucu dari Wasidi yang masih duduk di kelas lima sekolah dasar. Kemudian sepupu dari Yusminardi yang berinisial R mengirimkan video tersebut kepada ayahnya yang berada di Jakarta. Belum diketahui siapa yang mengunggah video tersebut ke media sosial sehingga menjadi viral sampai saat ini.

Ketika diperiksa oleh polisi tersangka menggaku emosi karena sang kakek mengungkit masalah uang yang diberiakan ketika tersangka ingin pulang ke Indonesia saat ia di Malaysia saat tersangka membentak kepada kakeknya. Disitulah puncak kemarahan tersangka yang tidak bisa dikendalikan yang 
akhirnya tersangka menganiaya kakeknya sendiri. Yusminardi mengaku khilaf dan sangat menyesali perbuatanya, dirinya juga sudah pasrah apabila mendapat ganjaran atas apa yang diperbuaynya,. Saat akan dibawa ke kantor polisi, kakek tidak membolehkan dan menyatakan sudah memaafkan atas semua yang dilakukan oleh cucunya. Sang kakek sama sekali tidak marah bahkan memohon agar cucunya tidak diborgol dibawa ke kantor polisi, sampai-sampai beliau memeluk dan menggecup cucunya sambal meneteskan air mata ketika tersangka dibawa ke Unit PPA Polres Kendal.

Disisi lain pelaku yang bernama Yusminardi merupakan seorang youtuber dengan akun bernama iyus sinting. Seketika saat video pengniayaan terhadap kakeknya viral, akun youtube iyus sinting dibanjir komentar negatif dan kecaman.

\section{BAB III PEMBAHASAN}

Pada kasus yang terjadi di atas saya akan dilakukan pembahasan. Yaitu dengan menggunakan buku Filsafat Manusia oleh A. W. Dewantara. Maraknya kekerasan saat ini membuat para peneliti ingin mengetahui penyebab terjadinya kekerasan. Banyak sekali penyebabnya, contohnya orang yang memiliki emosional tinggi, orang yang memiliki gangguan jiwa atau orang yang memiliki motif balas dendam.

Kasus yang terjadi di daerah Kendal yaitu cucu yang menendang dan memukuli kakeknya sendiri menjadi topik bahasan warga net maupun masyarakat. Pasalnya peristiwa ini terjadi hanya karena hal sepele, yaitu pakan ikan yang ada di bak mandi. Pelaku adalah pemuda bernama Yusminardi (22), ia mengaku tidak dapat mengendalikan emosi ketika pelet ikan masuk ke dalam mulutnya ketika ia menggosok gigi.

Pelaku yang tidak dapat mengontrol emosinya menganiaya kakeknya sendiri. Dilihat dari sudut pandang norma agama pelaku sangat dilarang melakukan hal tersebut karena termasuk sifat durhaka kepada orang yang lebih tua. Dilihat dari sudut pandang hukum tindakan yang dilakukan pemuda ini merupakan tindakan kriminal yang harus ditindaklanjuti oleh pihak yang berwajib, unruk kemudian diberikan ganjaran sepadan atau bahkan juga didenda. 
Apakah yang terjadi pada pelaku sampai melakukan hal ini?, mungkin dapat dilakukan pemeriksaan kejiwaan atau sejenisnya, karena bisa jadi pelaku mengalami gangguan psikologis. Jika dipikirkan menggunakan akal sehat tidak mungkin seseorang tega menyakiti anggota keluarganya sendiri jika seorang tersebut memiliki pemikiran yang normal. Jika seorang tersebut tega melakukan hal seburuk itu terhadap keluarga mungkin ia memiliki masalah, sakit hati, masalah kejiwaan atau mengininkan sesuatu dan tidak dipenuhi. Tetapi ada juga yang mel;akukan karena ego yang tinggi.

Seorang manusia yang baik akan selalu berpikir menggunakan akal sehatnya sebelum melakukan sesuatu. Seharusnya manusia yang dikaruniai akal budi juga harus bisa menahan diri dari amarah, agar terhindar dari hal- hal yang tidak diinginakan. Manusia harus senantiasa belajar tentang budi pekerti, manusia harus bisa membedakan hal baik dan hal yang buruk. Manusia yang paham benar tentang hal baik dan buruk pasti akan lebih terhindar dari perbuatan tercela meskipun manusia pasti pernah melakukan kesalahan.

Banyak sekali cara agar memiliki pengetahuan yang luas tentang bebaikan yang harus dijalani dalam hidup, misalnya dari buku, dari internet, dari lingkungan masyarakan dan yang paling dekat yaitu lingkungan keluarga. Lingkungan memang sangat berpengaruh terhadap perkembangan perilaku seseorang dansangat berpengaruh besar. Keluarga merupakan lingkungan yang paling menentukan karakter yang akan dimiliki anggota keluarganya. Jika dididik baik dari keluarga kemungkingan menjadi seorang yang baik. Akan tetapi apabila seorang tersebut masuk kedalam lingkungan masyarakat yang kurang baik memungkinkan juga seorang yang pada dasarnya adalah orang baik menjadi seorang yang jahat atau berperilaku buruk karena pengaruh luar atau lungkungan masyarakat tadi. Kenapa bisa begitu karena sanksi apabila tidak mengikuti pergaulan atau kebiasaan masyarakat sangatlah berat, misal dikucilkan,atau tidak ada yang membantu jika kesulitan. Sebagai manusia yang memiliki akal budi seharusya harus bisa menyaring semua ilmu atau pengalaman yang diperoleh selama hidup untuk dijadikan suatu pelajaran atau motivasi hidup. 


\section{BAB IV PENUTUP}

\section{Kesimpulan}

Dari penjelasan di atas dapat disimpulkan bahwa kekerasan merupakan tindakan kriminal dan harus ditindaklanjuti oleh pihak yang berwajib. Kekerasan merupakan perbuatan yang melanggar norma. Orang yang melakukan tindak kriminal atau kekerasan harus diberi pengarahan atau pengetahuan tentang hal baik dan hal buruk.seorang yang melakukan tindak kriminal pasti memiliki latar belakang atau masalah tertentu sehingga melakukan tindak tersebut. Manusia yang baik harus selalu memikirkan terlebih dahulu semua tindakan yang akan dilakukan. 


\section{REFERENSI}

DEWANTARA, A. W. (2016). GOTONG-ROYONG MENURUT SOEKARNO DALAM PERSPEKTIF AKSIOLOGI MAX SCHELER, DAN SUMBANGANNYA BAGI NASIONALISME INDONESIA (Doctoral dissertation, Universitas Gadjah Mada).

Dewantara, A. W. (2015). Filosofi Pendidikan yang Integral dan Humanis dalam Perspektif Mangunwijaya. JPAK: Jurnal Pendidikan Agama Katolik, 13(7), 3-9.

Dewantara, A. (2017). Filsafat Moral (Pergumulan Etis Keseharian Hidup Manusia).

Dewantara, A. W. (2013). Merefleksikan Hubungan antara Etika Aristotelian dan Bisnis dengan Studi Kasus Lumpur Lapindo. Arete, 2(1), 23-40. 